\title{
Table of judgments and decisions of courts
}

\section{INTERNATIONAL CASE LAW}

\section{Permanent Court of International Justice}

Certain German Interests in Polish Upper Silesia (Germany v. Poland) (Merits)

[1926] PCIJ Report Series A No 7 18

Settlers of German Origin in Poland, Advisory Opinion [1923] PCIJ Reports Series

B No 6 123,152

\section{International Court of Justice}

Armed Activities on the Territory of the Congo (Democratic Republic of the Congo

v. Uganda) (Judgment) [2005] ICJ Reports 168 $80,86,90,119$

Interpretation of the Agreement of 25 March 1951 between the WHO and Egypt

(Advisory Opinion) [1980] ICJ Reports 73

Jurisdictional Immunities of the State (Germany v. Italy: Greece intervening)

Application by the Hellenic Republic for Permission to Intervene (Order of 4

July 2011), Separate Opinion of Judge Cançado Trindade 104

Legal Consequences of the Construction of a Wall in the Occupied Palestinian

Territory (Advisory Opinion) [2004] ICJ Reports 136 80,81

Legality of the Use by a State of Nuclear Weapons in Armed Conflict (Advisory

Opinion) [1996] ICJ Reports 66 179

Legality of the Threat or Use of Nuclear Weapons (Advisory Opinion) [1996] ICJ

Reports 226 $71,76,80,81,198$

Military and Paramilitary Activities in and against Nicaragua (Nicaragua v. US)

(Judgment) [1986] ICJ Reports 14 ..... 2, 22, 33, 54, 94, 114, 124, 132, 199

North Sea Continental Shelf Cases (Federal Republic of Germany v. Denmark;

Federal Republic of Germany v. Netherlands) (Judgment) [1969] ICJ

Reports 3

Oil Platforms (Iran v. US) (Judgment) [2003] ICJ Reports 161

The Application of the Convention on the Prevention and Punishment of the Crime of Genocide (Bosnia and Herzegovina v. Serbia and Montenegro) (Judgment)

[2007] ICJ Reports 91 (Genocide case) $119,121,127,130$

The Continental Shelf (Libyan Arab Jamahiriyah/Malta) (Judgment) [1985] ICJ

Reports 13 2 


\section{European Court of Human Rights}

Al-Jedda v. the United Kingdom, Application No. 27021/08, Judgment (7 July 2011) 182,183

Banković et al. v. Belgium et al., Decision as to the admissibility of Application No. 52207/99 (12 December 2001)

Behrami and Saramati v. France et al., Decision as to the Admissibility of

Application Nos. 71412/01 and 78166/01 (2 May 2007) $182-184$

\section{Inter-American Court of Human Rights}

Juan Carlos Abella v. Argentina (1997) Inter-Am Ct HR, Judgment of 18 November 1997, Report 55/97, Case 11.137 68

Rochela Massacre v. Colombia (2007) Inter-Am Ct HR, Judgment of 11 May 2007, Report No. 42/02, Case 11.995 120

\section{International Criminal Court}

Prosecutorv. Bahar Idriss Abu Garda, Decision on the Confirmation of Charge,

ICC-02/05-02/09 (8 February 2010)

Prosecutorv. Jean-Pierre Bemba Gombo, Decision on the Confirmation of

Charges, ICC-01/05-01/08 (15 June 2009) $56,64,89,122$

Prosecutorv. Thomas Lubanga Dyilo, Decision on the Confirmation of Charges, ICC-01/04-01/06 (29 January 2007) $64,67,125$

Prosecutorv. Thomas Lubanga Dyilo, Judgment pursuant to Article 74 of the Statute, ICC-01/04-01/06 (14 March 2012) .......... 51, 52, 55, 58, 94, 122, 125

Situation in the Republic of Kenya, Decision Pursuant to Article 15 of the Rome Statute on the Authorization of an Investigation into the Situation in the Republic of Kenya, ICC-01/09 (31 March 2010) 66

\section{International Criminal Tribunal for the former Yugoslavia}

Prosecutorv. Aleksovski (Trial Judgment) IT-95-14/1-T (25 June 1999) .... 101, 102 Prosecutorv. Aleksovski (Appeal Judgment) IT-95-14/1-A (24 March 2000) ..... 125 Prosecutor v. Blaskić (Trial Judgment) IT-95-14-T (3 March 2000) ............ 94, 125 Prosecutorv. Blaskić (Appeal Judgment) IT-95-14-A (29 July 2004) ................. 145 Prosecutor v. Boškoski and Tarčulovski (Trial Judgment) IT-04-82-T (10 July 2008)

Prosecutorv. Brdjanin (Trial Judgment) IT-99-36-T (1 September 2004) .......... 145 Prosecutorv. Delalić et al. (Trial Judgment) IT-96-21-T (16 November 1998) $51,55,64$

Prosecutor v. Delalić et al. (Appeal Judgment) IT-96-21-A (20 February 2001)

Prosecutorv. Furundzija (Trial Judgment) IT-95-17/1-T (10 December 1998) .... 73 Prosecutorv. Galić (Appeal Judgment) IT-98-29-A (30 November 2006) ...... 73, 76 
Prosecutor v. Hadžihasanović and Kubura (Decision on Joint Defence Interlocutory Appeal of Trial Chamber Decision on Rule 98bis Motions for Acquittal)

IT-01-47-AR73.3 (11 March 2005) 73,74

Prosecutor v. Haradinaj, Balaj and Brahimaj (Trial Judgment) IT-04-84-T (3 April 2008) $63-65,67,68$

Prosecutorv. Kordić and Čerkez (Trial Judgment) IT-95-14/2-T (26 February 2001) 125

Prosecutorv. Kordić and Čerkez (Appeal Judgment) IT-95-14/2-A (17 December 2004) $.76,125,145,146$

Prosecutor v. Kunarac, Kovac and Vukovic (Trial Judgment) IT-96-23-T and IT-96-23/1-T (22 February 2001) 80

Prosecutor v. Limaj, Bala and Musliu (Trial Judgment) IT-03-66-T (30 November 2005) $63,65,67$

Prosecutorv. Milosevic (Decision on Motion for Judgment of Acquittal) IT-02-54-T (16 June 2004)

Prosecutor v. Naletilić (Trial Judgment) IT-98-34-T (31 March 2003) ....... 125, 145

Prosecutorv. Rrajic (Review of the Indictment pursuant to Rule 61 of the Rules of

Procedure and Evidence) T-95-12-R61 (13 September 1996) 99,102

Prosecutor v. Strugar (Trial Judgment) IT-01-42-T (31 January 2005) .......... 73, 77

Prosecutor v. Tadić (Jurisdiction Appeal) IT-94-1-AR72 (2 October 1995) ....... 3, 7, $17,21,51,55,61,63,68,72,73,77,94,102$

Prosecutorv. Tadić (Trial Judgment) IT-94-1-T (7 May 1997) 63,130 Prosecutorv. Tadić (Appeal Judgment) IT-94-1-A (15 July 1999) ....... 94, 100, 114, $117,119,120,121,122,123,125,126,127,128,129,131$, $136,137,138,139,140,141,145$

\section{International Criminal Tribunal for Rwanda}

Prosecutorv. Akayesu (Trial Judgment) ICTR-96-4-T (2 September 1998) ... 64, 68,

\section{Special Court for Sierra Leone}

Prosecutorv. Brima, Kamara and Kanu (Trial Judgment) SCSL-04-16-T (20 June 2007) 125,127

Prosecutorv. Sesay, Kallon and Gbao (Trial Judgment) SCSL-04-15-T (2 March 2009)

\section{Arbitral Decisions}

Charles J Jansen v. Mexico, Mexico-US Claims Committee (1868), published in J.

B. Moore, History and Digest of the International Arbitrations to Which the

U.S. Has Been a Party (US Government Printing Office, 1898) .... 152

Great Britain v. Costa Rica, 1 Reports of International Arbitral Awards 369

(18 October 1923) (Tinoco Concessions case) 153,154 


\section{DOMESTIC CASE LAW}

\section{Belgium}

Cour Militaire de Bruxelles (Military Court of Brussels), Centre pour l'égalité des chances et la lutte contre le racisme v. C. et B., Judgment of 17 December 1997

\section{Colombia}

Constitutional Court of Colombia, Sentencia C-291/07 of 2007 (English translation available in Sassòli and Bouvier (2011), Vol. III, Case No. 244)

\section{Democratic Republic of the Congo}

Military Prosecutor v. Bongi Massaba, Criminal Trial Judgment and Accompanying Civil Action for Damages, RP No 018/2006; RMP No 242/ PEN/06 (24 March 2006)

\section{Israel}

HCJ 769/02 Public Committee against Torture in Israel v. Government of Israel (13 Dec 2006) $3,61,74,88$

Military Prosecutor v. Omar Mahmud Kassem and Others, Judgment of the Israeli Military Court (13 April 1969), published in English in 42 International Law Reports 470 (1971)

\section{The Netherlands}

The Netherlands (Ministry of Defence and Ministry of Foreign Affairs) v. Hasan Nuhanovic, Supreme Court of the Netherlands (6 September 2013). English translation available online: https://www.rechtspraak.nl/ Organisatie-en-contact/Organisatie/Hoge-Raad-der-Nederlanden/ Supreme-court-of-the-Netherlands/Documents/12\%2003324.pdf .... 181, 183 Hasan Nuhanovic v. the Netherlands, Court of Appeal in The Hague, Civil Law Section (5 July 2011), LJN: BR5388; 200.020.174/01. English translation available online: http://zoeken.rechtspraak.nl/detailpage.aspx ?ljn= BR5388

Mehida Mustafic-Mujic, Damir Mustafic, and Alma Mustafic v. the Netherlands, Court of Appeal in The Hague, Civil Law Section (5 July 2011), LJN: BR5386; 200.020.173/01. English translation available online: http:// zoeken.rechtspraak.nl/detailpage.aspx?ljn=BR5386 


\section{United Kingdom}

Judicial Committee of the Privy Council, Public Prosecutor v. Koi et al. (1967) [1968] AC 829

Court of Appeal (Criminal Division), Regina v. Gul [2012] EWCA Crim 280 (22 February 2012) $163,167,188$

High Court (Queen's Bench Division), Republic of Somalia v. Woodhouse, Drake and Carey (Suisse) SA et al. (13 March 1992)

Asylum and Immigration Tribunal, GS (Existence of Internal Armed Conflict) Afghanistan v. Secretary of State for the Home Department, CG [2009] UKAIT 00010 (23 February 2009)

Asylum and Immigration Tribunal, $\mathrm{KH}$ (Article 15(c) Qualification Directive) Iraq v. Secretary of State for the Home Department, CG [2008] UKAIT 00023 (25 March 2008)

\section{United States of America}

US Supreme Court, Ex Parte Quirin, 317 US 1 (1942)

US Supreme Court, Hamdan v. Rumsfeld 548 US 557 (2006) 61,163

US Supreme Court, US v. The Three Friends 166 US 1 (1897) 18,20

US Supreme Court, Williams v. Bruffy, 96 US 176 (1877)

Ninth Circuit Court of Appeals, In re Territo, 156 F.2d 142 (1946) 143

Court of Appeals of New York, Salimoff \& Co and Others v. Standard Oil Company of New York, 262 NYS 220 (1933)

District Court for the Southern District of Florida, US v. Noriega, 808 F. Supp. 791 (S.D. Fla. 1992) 